\title{
Hypothetical learning trajectory (HLT) for proof logic topics on algebra course: What're the experts think about?
}

\author{
Riza Agustiani', Rahmat Nursalim² \\ ${ }^{1}$ Mathematics Education Study Program, UIN Raden Fatah, Palembang, Indonesia \\ ${ }^{2}$ Mathematics Study Program, University of Bengkulu, Indonesia \\ \rizaagustiani_uin@ @radenfatah.ac.id
}

\section{Article Information \\ Submitted April 13, 2019 \\ Revised May 17, 2020 \\ Accepted May 19, 2020}

Keywords

Algebra; Hypothetical Learning

Trajectory; Proof Logic.

\begin{abstract}
Proof has a role in the formation and development of mathematics in the history of mathematics. The ability to construct proof is one indicator of mathematical reasoning which is an important component of mathematics learning outcomes, especially in Algebra. This qualitative research aims to describe the design process of the Hypothetical Learning Trajectory for Proof Logic Topics. This research is based on design research. This research consists of three stages: preparing for the experiment, the design experiment, and the retrospective analysis. Data collection techniques in this research are walkthrough and interview. The walkthrough and interview were conducted in the first stage of design research (preparing the experiment) with two activities: expert review and reader proof to collect materials to revise the HLT. Four experts participated in the expert review. The experts are chosen based on the experience, both research experience, and teaching experience. The result of this research is the design of HLT for proof logic topics consist of four activities: reading proof, completing proof, examining proof, and Constructing proof. The four activities were well-done on the design experiment stage.
\end{abstract}

\section{INTRODUCTION}

Proof in mathematics is important things that always need to understand mathematics, although every mathematical statement that has been written in a textbook is a statement that has been proven before. To establish a fact with certainty is the most basic motivation why people need to prove a mathematical statement, namely to ensure that what has been considered true is true (Suandito, 2017). The proof is important in mathematics both as a component of mathematics and as a tool for learning mathematics. Most experts consider proof to be the basis of mathematical structure in two important respects, namely mathematics subjects and the practice of mathematicians (Hanna \& Villiers, 2012; Sopamena, 2017).

The method of proof is generally divided into two, namely direct proof and indirect proof. Both methods relate to two styles of concluding namely direct inference and indirect inference (Sidharta \& Gunarsa, 2016). In direct proof, the inference whose conclusions are drawn from one premise (the proposition used for concluding). The conclusion drawn cannot be wider than the premise. In indirect inference, an inference whose conclusion is drawn from two or more premises. The process of reason creates a new proposition based on merging old propositions, meaning that there is a new premise that can be in the form of assumptions.

Algebra is one of the mathematics courses that are difficult to learn and difficult to teach. From the student's point of view, this difficulty, for example, is caused by concepts in Algebra that are very abstract, many examples of concepts, are not well recognized by students, many

$\begin{array}{ll}\text { How to cite } & \text { Agustiani, R., \& Nursalim, R. (2020). Hypothetical learning trajectory (HLT) for proof logic topics on algebra } \\ & \text { course: What're the experts think about?. Al-Jabar: Jurnal Pendidikan Matematika, 11(1), 101-110. } \\ \text { E-ISSN } & \text { 2540-7562 } \\ \text { Published by } & \text { Mathematics Education Department, UIN Raden Intan Lampung. }\end{array}$


students are not familiar with deductive proof. (Arnawa, 2010). In learning Algebra, it is necessary to develop algebraic reasoning through developing arithmetic generalizations in the early classes when algebra begins to be introduced, developing divergent thinking skills (think in a variety of ways), to training The Algebraic Habits of Mind (Andriani, 2015). Findel argues that the algebra field contains many definitions, lemmas, and theorems so that the ability to Construct proof is an important ability for students (Yudhanegara \& Lestari, 2017). Furthermore, a research result reveals the difficulties experienced by prospective teacher students in Constructing proof including courses that are difficult for prospective teacher students as a concept for Constructing proof, awareness of the importance of the ability to Constructing proof for mathematics education, and the ability to construct proof concerning the professional life of a prospective teacher. (Güler, 2016). Therefore, the material on proof logic needs to be included in the introductory topic of algebra.

Proof logic material that has been studied in basic mathematics courses must be packaged in a more applicable form in achieving more specific goals, which is to help students be trained in Constructing proof. Educators play a role in integrating the goals and flow of learning activities with the learning path and learning pathways of students to facilitate students in the construction of mathematical ideas and train their thinking skills specifically to construct a proof. Therefore, educators need to design a hypothesis and anticipate the learning flow and the thinking flow of students who are equipped with learning activities. For this purpose, the term Hypothetical Learning Trajectories (HLT) was introduced, which is a hypothesis about the learning path in learning a mathematical concept or mental activity in constructing mathematics (Prahmana, 2017).

HLT is consist of three components, they are: learning objective, learning activity, and the conjecture of student thinking (Andrews-Larson et al., 2017). The three components of HLT are interconnected and influence each other. The benefits of HLT as a tool to support learning are another form of content pedagogical knowledge (Agustiani, 2015; Wright, 2014). In the design of the HLT of proof logic for the introduction to the Algebra, course contains several integrated activities to understand students gradually according to the levels of thinking.

In previous studies regarding the application of conditioning-reinforcement-scaffolding (CRS) theory in Group Theory learning, The findings show that the ability to Construct mathematical proofs through the application of CSR theory was significantly better than the ability to Construct mathematical proofs through the application of constructivist theory (Yudhanegara \& Lestari, 2017). This indicates that the three steps can be used as a starting point for the development of HLT Proof logic material for introduction to Algebra. Furthermore, research with the title Using Mathematics History to Strengthen Geometric Proof Skills gives the result that historical activities can be a recommendation as learning activities in mathematics in the classroom because activities taken from the history of mathematics can attract students' interest (Ozdemir et al., 2012). The research proves that the process of finding proof can be a fun activity if it starts from something that makes sense for students.

Based on the background that has been described, the authors conclude the need to develop Hypothetical Learning Trajectory (HLT) Proof Logic material to help students practice the ability to Construct proof to support the learning outcomes of Algebra (Linear Algebra and Algebra Structure). At the beginning of the development process, design research will be carried out. One focus of design research is the development of theory in the learning process 
(Prediger et al., 2015). Design research is carried out to design and implement HLT by carrying out experiments and then analyzing the results of the implementation and the final ability achieved by students. This study aims to describe the design process of the Hypothetical Learning Trajectory Proof Logic Material.

\section{METHODS}

This type of research is Design Research (DR). This research is a qualitative research that aims to describe the design process of Hypothetical Learning Trajectory Proof Logic Material and its application in the Algebra Structure course and the results of students' ability to construct a proof. This research is broadly divided into 3 phases, preparing for the experiment, the design experiment, and the retrospective analysis. (Gravemeijer, 2016; Prahmana, 2017). In this article, the focus of the discussion is only in the preparation phase of the experiment activities (preparing for the experiment).

In the preparation phase of the experiment activities (preparing for the experiment), the researcher designs the HLT for the learning of proof logic material. HLT contains learning objectives (mathematical goals), teaching and learning activities, and the conjecture of student thinking. The purpose of this stage is to prepare research including theoretical preparation, designing HLT, making HLT supporting instruments, site preparation, and research subjects. In the theory preparation stage, the researcher collects corresponding references regarding algebraic learning, proof compilation, HLT, and proof logic. After sufficient theory is gathered, using the existing theory the researcher designs the HLT and Constructs the research instruments in the form of the HLT Tables, Activity Sheets for each activity in the HLT (4 activities), Initial Ability Test Questions and Final Test Questions. The HLT and the four instruments submitted to the expert review activities and readability test to obtain instrument feasibility data.

In the expert review activity, the instrument was reviewed by 4 experts who were lecturers from various universities with relevant knowledge. The selection of experts considers the length of service as a lecturer, the level of education, and the quantity and quality of research that has been carried out. The feasibility data for the HLT Instrument was collected at the experimental preparation stage through expert review activities and readability testing. Data collected through the walkthrough technique. In this study data collection activities through the walkthrough technique began by providing HLT and its supporting instruments to 4 lecturers in the expert review activities complete with advice sheets and comments for each assessment component (instrument). Through this technique data obtained in the form of suggestions and written comments from 4 lecturers as experts. After carefully reading the suggestions and comments, the researcher then held discussions with the experts and students as a media for confirmation and discussion to formulate matters that were subject to the revision of the HLT and its supporting instruments. Discussion activities are carried out separately, using an open question form, and the results of the discussion are recorded in writing by the researcher.

\section{RESULTS AND DISCUSSION}

In the expert review activity, the instrument was reviewed by 4 experts who were lecturers from various universities with relevant knowledge. Researchers chose 2 Doctor of Mathematics Education (Ha and MWA), 1 Candidate Doctor of Mathematics Education who is teaching 
Algebra course and researching Algebra (YF), 1 Master of Applied Mathematics who has studied Algebra (RN). The four experts were asked to assess whether the HLT and HLT supporting instruments that had been prepared were suitable for use in the Experiment activities based on their respective expertise both theoretically and practically.

The expert review activity begins by providing the HLT and the Research Supporting Instrument to be commented in writing on the sheet provided. After the four experts give their views in the form of written comments, the researcher analyses the results by detailing the matters that are considered necessary to be discussed with the expert. The discussion between the researcher and the expert is intended to confirm the details of the planned revision that the researcher concludes based on the expert's written comments as a whole. The following are comments and revision results of the expert review activities for HLT and other supporting instruments.

HLT which is arranged as an initial design is called the initial prototype. The initial prototype HLT consisted of 4 teaching-learning activities, namely the activity of reading proof, completing proof, evaluating proof, and Constructing proof. In the expert review activity, the researcher intends to obtain an expert judgment on the relevance of the activities to achieve the expected goals along with the researcher's hypothesis about the conjecture of students' thinking. Also, researchers emphasize questions to experts about the order in which activities are proposed whether they can be justified theoretically and practically.

Based on expert comments, researchers arrange things that are considered necessary to be discussed with experts. In outline, two things are subject to discussion between researchers and experts: students' understanding about the use of two types of proof methods (direct proof and indirect proof) that will be used in HLT activities and the need to make separate steps and additions one activity in HLT is "evaluating proof with guidance". After the discussion with the experts, the following revision materials for the initial prototype HLT: Both methods of proof, i.e. direct and an indirect proof will be used in each activity; The third activity, which is "evaluating proof", experiences a change in name to "examining proof". The activity content is made into two sub-activities, i.e. examine proof with instructions and examine proof without guidance.

\section{Activity 1: Reading Proof}

The purpose of the first activity "Reading Proof" is to introduce the parts that must be present in the sentence of proof, the types of proof logic, and the reasoning used in Constructing proof (deductive reasoning). On this first activity sheet, students read the proof of the theorems both direct and indirect proof, then asked to explain their understanding by providing a description of what should be contained in the sentence of proof, the type of proof logic used, the rationale of the sentence/statement written as part of the proof and asking questions about the logic of proof that is not yet understood. The following details are the command/question contained in activity sheet 1 Reading Proof.

Table 1. Commands on Activity Sheet 1 Reading Proof

\begin{tabular}{cl}
\hline No & \multicolumn{1}{c}{ Command } \\
\hline $1 / 5$ & $\begin{array}{l}\text { Read carefully the proof of the following basic group theorems! } \\
\text { (Students are given complete proof, direct proof for question number 1 and indirect proof } \\
\text { for question number 5) }\end{array}$ \\
After reading the proof of the theorem, then write down the premises (statement / closed \\
sentence) of each statement of proof!
\end{tabular}


3/7 After reading the proof of the theorem, then write down the things you have understood (in a few points, if any) in the box below!

4/8 From the results of the class, discussion write in full the conclusions / new understanding that you get (If any)!

At the expert review for activity 1, the researcher focused the questions on the expert about the clarity of the command sentence/question, the completeness, and the level of difficulty of proving theorems presented. The researcher wants to know whether Activity 1 can be used to carry out the activity of reading the proof according to the activity's objective. Based on expert comments, researchers arrange things that are considered necessary to be discussed with experts. In outline, two things are subject to discussion between researchers and experts: The need to specify each statement in the theorem-proof section to help students to refer to their understanding; The question sentence is made in more detail about the type of proof method used along with the premise of each statement, what is known and wants to be proven, and the concept contained. After holding discussions with experts, the researcher decided that both of these things were worthy of consideration for the revision of Activity Sheet 1 Reading the Proof.

\section{Activity 2: Completing Proof}

The purpose of the second activity "Completing Proof" is to train students to identify sentences/statements of proof that must be present in the proof sentence (incomplete), the use of proof logic, and the reasoning used in Constructing the proof (deductive reasoning). In this second activity sheet, students are asked to read the theorem-proof both direct and indirect proof that has been presented where some sentences/statements are omitted. Then, students are asked to complete the proof, rational sentence of the sentence/statement written as part of the proof sentence, determine the type of proof of logic used, ask questions about proof logic that are not yet understood. The following details are the command/question contained in the activity sheet 2 Completing Proof.

Table 2. Commands on Activity Sheet 2 Completing Proof

\begin{tabular}{cl}
\hline No & \multicolumn{1}{c}{ Command } \\
\hline $1 / 4$ & $\begin{array}{l}\text { Read carefully the proof of the following basic group theorems! (Students are } \\
\text { given incomplete proof, direct proof for question number 1 and indirect proof } \\
\text { for question number 4) }\end{array}$ \\
$2 / 5$ & $\begin{array}{l}\text { After reading the proof of the theorem in point 1, then write down the things } \\
\text { that you think are incomplete (if any) of the proof of the theorem! }\end{array}$ \\
$3 / 6$ & Write the complete proof of the theorem on point 1!
\end{tabular}

Not much different from the expert review stage for activity sheet 1 , the researcher wants to know whether Activity Sheet 2 that has been constructed can be used to carry out activities to complete the proof following the activity objective points. Based on expert comments, researchers arrange things that are considered necessary to be discussed with experts. In outline, two things became the subject of discussion between researchers and experts: The need to specify each statement in the theorem-proof section as in the first activity sheet; The need to be variation in eliminating the premise/statement to be completed. The revision aims to enable students to understand the sequence of proof steps. After carrying out discussions with experts, the researcher decided that both of these things were worthy of consideration for the revision of Activity Sheet 2 Completing Proof by adding concepts that students thought needed to be added in completing the proof. 


\section{Activity 3: Evaluating Proof}

The purpose of the third activity "Evaluating Proof" is to train students to evaluate the sentences/statements of proof presented by identifying errors. On this third activity sheet, students are asked to read theorem's proofs, both direct and indirect proof that has been presented where there is a logical fallacy in some of the sentences/statements of proof. The students are asked to identify errors and improve the proof, determine the appropriate type of proof of logic, and /or ask questions about proof logic that are not yet understood. The following details are the command/question contained in the activity sheet 3 Evaluating Proof.

Table 3. Commands on Activity Sheet 3 Evaluating Proof

\begin{tabular}{cl}
\hline No & \multicolumn{1}{c}{ Command } \\
\hline $1 / 4$ & $\begin{array}{l}\text { Read carefully the proof of the following basic group theorems! (Students are given } \\
\text { proof by logic/wrong concept, direct proof for question number } 1 \text { and indirect proof } \\
\text { for question number 4) }\end{array}$ \\
$2 / 5$ & $\begin{array}{l}\text { After reading the proof of the theorem, then write the things that are FALSE in your } \\
\text { opinion (if any) in the box below! }\end{array}$ \\
$3 / 6$ & Write the right proof of the theorem on point 1/4!
\end{tabular}

The researcher wants to find out whether Activity Sheet 3 that has been constructed can be used to carry out activities evaluating proof according to the purpose of the activity. Based on expert comments, there are two things that worthy of consideration for the revision of Activity Sheet 3 Evaluating the Proof.: The need to specify each statement in the theorem-proof section as in the first activity sheet; It is necessary to highlight the statement/sentence evaluated in the first problem to familiarize students with recognizing the false statement/sentence or error-proof logic. One expert also objected to the name of the third activity, so the researcher changes the name of the third activity to be "Examining Proof'.

\section{Activity 4: Constructing Proof}

The purpose of the fourth activity "Constructing Proof" is to train students to construct their sentences/statements of proof from several theorems provided with the correct sentence and proof of logic. On this fourth activity sheet, students are asked to construct proof from several theorems that are presented using both direct and indirect methods. The following details are the command contained in activity sheet 4 Constructing Proof.

Table 4. Commands on Activity Sheet 4 Constructing Proof

\begin{tabular}{cl}
\hline No & \multicolumn{1}{c}{ Command } \\
\hline $1 / 4$ & $\begin{array}{l}\text { Read carefully the proof of the following basic group theorems! (Students are given } \\
\text { proof by logic/wrong concept, direct proof for question number } 1 \text { and indirect proof } \\
\text { for question number 4) }\end{array}$ \\
$2 / 5$ & $\begin{array}{l}\text { In your opinion, the theorem in point } 1 \text { is more effectively proven using direct } \\
\text { proof or indirect proof? Explain your reasons! }\end{array}$ \\
$3 / 6$ & Write the right proof of the theorem on point $1 / 4 !$
\end{tabular}

The researcher aims to know whether Activity Sheet 4 that has been compiled can be used to carry out activities to construct the proof following the activity objective points. Based on expert comments, researchers arrange things that are considered necessary to be discussed with experts. After conducting discussions with experts, the researcher decided that both of these things were worthy of consideration for the revision of Activity Sheet 4 Constructing Proof: The need to make more specific questions for each proof to guide students to compile the proof; Consider the level of difficulty of the questions. 
According to the results of the expert review (especially MWA), the activities contained in the HLT Logic Proof need to provide more diverse examples of proof using both methods of proof (direct and indirect). In line with the CRS theory (Yudhanegara \& Lestari, 2017). It is done to prepare and strengthen students' understanding of the two types of proof methods in the activities of understanding proof, as well as providing quality and diverse scaffolding in the activities of completing proof and examining proof. Furthermore, the four experts (especially $\mathrm{Ha}$ and $\mathrm{RN}$ ) were very concerned about the need for proof of construction, the proof is not given as the finished item, but it should be constructed by students through discussion in small groups. This is in line with APOS theory, lecturers need to invite students to criticize the proof that has been made by each group. By using the scaffolding technique, lecturers lead students to arrive at the correct proof (Arnawa, 2010; Arnon et al., 2014; García-Martínez \& Parraguez, 2017).

After carrying out discussions with experts/experts at the expert review stage, an idea emerged to see the linkages of the activities contained in the HLT Proof Logic Material related to the level of thinking in Bloom's Taxonomy. Expert 3 (YF) suggested this related to researchers' questions about the sequence of activities completing proof and evaluating proof activities. Bloom's taxonomy focuses more on cognitive thinking abilities than on psychomotor and affective abilities, this taxonomy makes teachers think that learning goals are behaviors about what a student can do/understand as a learning outcome (Adams, 2015). Related to the sequence of activities at HLT, the discussion continues on the reference level of thinking in Bloom's Taxonomy as in Table 5 (Armstrong, 2016).

Table 5. Thinking Levels Based on Revised Bloom's Taxonomy

\begin{tabular}{ll}
\hline \multicolumn{1}{c}{ Level } & \multicolumn{1}{c}{ Description } \\
\hline Remembering (C1) & $\begin{array}{l}\text { The ability to mention information/ knowledge stored } \\
\text { The ability to understand instructions and affirm } \\
\text { understanding/meaning, ideas or concepts that have been taught } \\
\text { either in oral, written or graphic/diagram form }\end{array}$ \\
The ability to do things and apply concepts in certain situations \\
Applying (C3) & $\begin{array}{l}\text { The ability to separate concepts into several components and connect } \\
\text { to gain an understanding of the concept as a whole } \\
\text { Analyzing (C4) } \\
\text { The ability to determine the degree of something based on certain } \\
\text { criteria or benchmark norms } \\
\text { The ability to combine elements into something new, complete and } \\
\text { coherent, or make something original }\end{array}$ \\
\hline
\end{tabular}

At Bloom's Taxonomic thinking level, evaluating activity is at the 5th level of thinking which is included in the higher-order thinking (HOT) category, one level below the level of Thinking: Creation. It becomes the basis for laying out the sequence of activities evaluating proof in the third-order (which was later revised to be "examining proof"). Based on the results of discussions with experts (especially $\mathrm{Ha}$ and YF), the activity of examining proof is then divided into two sub-levels. In the first sub-level, students are given instructions in several statements of proof which are marked as statements that are likely to be mistaken. At the second sub-level, students are asked to directly evaluate the proof that has been written complete with the truth value "False".

Looking at these two phenomena and examining the characteristics of the cognitive level according to Bloom's Taxonomy and the activities contained in the HLT Proof Logic Material, 
the researcher analyzes the relationship between Bloom's Taxonomy and HLT Proof Logic. Bloom has stated that there are two levels in students' mathematical thinking, Low Order Thinking for the C1-C3 category, and High Order Thinking for the C4-C5 category (Merta Dhewa et al., 2017). In line with these two levels, the activities contained in the HLT Proof Logic Material are also divided into two levels, Low Order Thinking (Activity 1 and Activity 2), and High Order Thinking (Activity 3 and Activity 4). The complete activities are presented in Table 6.

Table 6. HLT Activities Proof Logic and Taxonomy of Bloom

\begin{tabular}{|c|c|c|c|}
\hline $\begin{array}{c}\text { HLT } \\
\text { activities } \\
\text { proof logic }\end{array}$ & $\begin{array}{l}\text { Bloom } \\
\text { Taxonomy }\end{array}$ & $\begin{array}{c}\text { The description of thinking level in Bloom } \\
\text { Taxonomy }\end{array}$ & $\begin{array}{l}\text { Cognitive } \\
\text { Level }\end{array}$ \\
\hline $\begin{array}{l}\text { Reading } \\
\text { Proof }\end{array}$ & $\begin{array}{l}\text { Remembering } \\
\text { (C1) }\end{array}$ & $\begin{array}{l}\text { The ability to mention information/ } \\
\text { knowledge stored }\end{array}$ & Low \\
\hline & $\begin{array}{l}\text { Understanding } \\
\text { (C2) }\end{array}$ & $\begin{array}{l}\text { The ability to understand instructions and } \\
\text { affirm understanding/meaning, ideas or } \\
\text { concepts that have been taught either in } \\
\text { oral, written or graphic/diagram form }\end{array}$ & Low \\
\hline \multirow[t]{2}{*}{$\begin{array}{l}\text { Completing } \\
\text { Proof }\end{array}$} & $\begin{array}{l}\text { Applying } \\
\text { (C3) }\end{array}$ & $\begin{array}{l}\text { The ability to do things and apply concepts } \\
\text { in certain situations }\end{array}$ & Middle \\
\hline & $\begin{array}{l}\text { Analyzing } \\
\text { (C4) }\end{array}$ & $\begin{array}{l}\text { The ability to separate concepts into } \\
\text { several components and connect to gain an } \\
\text { understanding of the concept as a whole }\end{array}$ & Middle \\
\hline $\begin{array}{l}\text { Examining } \\
\text { Proof }\end{array}$ & $\begin{array}{l}\text { Evaluating } \\
\text { (C5) }\end{array}$ & $\begin{array}{l}\text { The ability to determine the degree of } \\
\text { something based on certain criteria or } \\
\text { benchmark norms }\end{array}$ & High \\
\hline $\begin{array}{l}\text { Constructing } \\
\text { Proof }\end{array}$ & $\begin{array}{l}\text { Creating } \\
\text { (C6) }\end{array}$ & $\begin{array}{l}\text { The ability to combine elements into } \\
\text { something new, complete and coherent, or } \\
\text { make something original }\end{array}$ & High \\
\hline
\end{tabular}

The results of other studies that support the division of levels of thought and activity to Construct proof are research on the level of students' ability to Construct proof based on information processing theory (Hasan, 2016). Based on these results it can be concluded that there are 3 levels of student thinking according to the level of students' ability to Construct student proof based on information processing theory, namely the high students, the middle students, and the low students. The low students are still struggling in processing information, knowledge, and understanding of the concepts needed in Constructing the proof is still very limited ( $\mathrm{C} 1$ and $\mathrm{C} 2$ ). The recommendation for students of this group according to HLT is the activity of reading proof where students are asked to examine the concepts used in Constructing the proof and the logic of the proof. Middle students have succeeded in processing information but failed in Constructing the arguments presented by middle students in the construction of the proof which is unclear and incomprehensible (C3 and C4). Based on the developed HLT, the recommendation for middle-level students is the activity of completing proof and examining proof where students are trained to apply and analyze the concepts needed in Constructing proof. For high students where the information processing component is functioning properly, the activity of Constructing Proof can be recommended.

\section{CONCLUSIONS}


This research resulted in a Hypothetical Learning Trajectory (HLT) of Proof Logic Material which contains 4 activities: reading proof, completing proof, examining proof, and constructing the proof. Some theories relevant to the HLT include Taxonomy Bloom, APOS, CSR, and Information Processing theory. Considering the theories, the experts have many revised recommendations regarding the order of activities based on the level of thinking, the selection of variations and the level of difficulty of the proof submitted to students, and the scaffolding used in the activity sheet.

Based on the results of this study, the researcher recommends several suggestions. The following are suggestions aimed at developing study programs in terms of curriculum improvement, teaching methodology, learning outcomes, and further research. The results of this study, in the form of HLT design Proof Logic Material in Algebra, can be a reference for lecturers of Algebra to be used in learning activities from Basic Algebra to Advanced Algebra. Looking at the experts' recommendation, HLT Proof Logic Material in Algebra Subjects can be developed into other fields of study, such as the fields of analysis and geometry, where proof logic becomes an important part of helping students understand mathematics. Further development can refer to taxonomies of thinking or other relevant theories especially the Learning Instruction Theory of the material.

\section{AUTHOR CONTRIBUTIONS STATEMENT}

how to be the lead researcher in this research. RN helped develop the research instrument.

\section{REFERENCES}

Adams, N. E. (2015). Bloom's taxonomy of cognitive learning objectives. Journal of the Medical Library Association: JMLA, 103(3), 152.

Agustiani, R. (2015). Profil pengetahuan pedagogik konten mahasiswa calon guru matematika dalam melaksanakan pembelajaran dengan pendekatan PMRI. Jurnal Pendidikan Matematika RAFA, 1(2), 288-305.

Andrews-Larson, C., Wawro, M., \& Zandieh, M. (2017). A hypothetical learning trajectory for conceptualizing matrices as linear transformations. International Journal of Mathematical Education in Science and Technology, 48(6), 809-829.

Andriani, P. (2015). Penalaran aljabar dalam pembelajaran matematika. Beta: Jurnal Tadris Matematika, 8(1), 1-13.

Armstrong, P. (2016). Bloom's taxonomy. Vanderbilt University Center for Teaching.

Arnawa, I. M. (2010). Mengembangkan kemampuan mahasiswa dalam memvalidasi bukti pada aljabar abstrak melalui pembelajaran berdasarkan teori APOS. Jurnal Matematika Dan Sains, 14(2), 62-68.

Arnon, I., Cottrill, J., Dubinsky, E., Oktaç, A., Roa Fuentes, S., Trigueros, M., \& Weller, K. (2014). APOS theory. A Framework for Research and Curriculum Development in Mathematics Education, 5-15. 
García-Martínez, I., \& Parraguez, M. (2017). The basis step in the construction of the principle of mathematical induction based on APOS theory. The Journal of Mathematical Behavior, 46, 128-143.

Gravemeijer, K. (2016). Design-research-based curriculum innovation. Quadrante, 25(2), 7 23.

Güler, G. (2016). The difficulties experienced in teaching proof to prospective mathematics teachers: Academician views. Higher Education Studies, 6(1), 145-158.

Hanna, G., \& Villiers, M. de. (2012). Proof and proving in mathematics education: The 19th ICMI study. Springer Science \& Business Media.

Hasan, B. (2016). Proses berpikir mahasiswa dalam mengkonstruksi bukti menggunakan induksi matematika berdasarkanteori pemerosesan informasi. APOTEMA: Jurnal Program Studi Pendidikan Matematika, 2(1), 33-40.

Merta Dhewa, K., Rosidin, U., Abdurrahman, A., \& Suyatna, A. (2017). The development of higher order thinking skill (HOTS) instrument assessment in physics study. IOSR Journal of Research \& Method in Education (IOSR-JRME), 7(1), 26-32.

Ozdemir, A. S., Goktepe, S., \& Kepceoglu, I. (2012). Using mathematics history to strengthen geometric proof skills. Procedia-Social and Behavioral Sciences, 46, 1177-1181.

Prahmana, R. C. I. (2017). Design research (Teori dan implementasinya: Suatu pengantar). Rajawali Pers.

Prediger, S., Gravemeijer, K., \& Confrey, J. (2015). Design research with a focus on learning processes: An overview on achievements and challenges. ZDM, 47(6), 877-891.

Sidharta, B. A., \& Gunarsa, A. (2016). Pengantar logika: Sebuah langkah pertama pengenalan medan telaah. Refika Aditama.

Sopamena, P. (2017). Karakteristik proses berpikir mahasiswa dalam mengonstruksi bukti keterbagian. Matematika Dan Pembelajaran, 5(2), 169-192.

Suandito, B. (2017). Bukti informal dalam pembelajaran matematika. Al-Jabar: Jurnal Pendidikan Matematika, 8(1), 13-24.

Wright, V. (2014). Towards a hypothetical learning trajectory for rational number. Mathematics Education Research Journal, 26(3), 635-657.

Yudhanegara, M. R., \& Lestari, K. E. (2017). How to develop students' experience on mathematical proof in group theory course by conditioning-reinforcement-scaffolding. 5th SEA-DR (South East Asia Development Research) International Conference 2017 (SEADRIC 2017). 